\title{
Schwannoma of the abdominal wall: updated literature review
}

\author{
Tommaso Panici Tonucci · Andrea Sironi · Eleonora Pisa · Benedetta Di Venosa · Luigi Bonavina (D)
}

Received: 14 April 2021 / Accepted: 19 April 2021 / Published online: 8 June 2021

(C) The Author(s) 2021

\begin{abstract}
Summary
Background Schwannoma is a benign tumor arising from Schwann cells of the peripheral nerves. It is often asymptomatic and can develop in the retroperitoneum, mediastinum, head and neck region, and upper and lower extremities. Schwannoma of the abdominal wall is extremely rare, but differential diagnosis with malignant neoplasms is important to reduce the risk of undertreatment.

Methods A narrative review of abdominal wall schwannoma was performed using PubMed, EMBASE, and Web of Science database and the search terms "schwannoma”, "neurinoma”, "neurilemmoma”, "soft tissue tumors", "neurogenic tumor", "rectus abdominis mass", "abdominal wall". In addition, the hospital charts were reviewed to report the personal experience.

Results Only 9 single case-reports of benign schwannoma of the abdominal wall were found in the English medical literature over the past decade. None of the patients received preoperative biopsy and all were resected with clear margins. In addition to the literature review, we report the case of a 58-year-old man referred for a palpable mass in the left upper abdominal quadrant. Ultrasonography and magnetic resonance imaging revealed a solid and well-encapsulated
\end{abstract}

T. Panici Tonucci · A. Sironi · Prof. L. Bonavina $(\bowtie)$

Department of Biomedical Sciences for Health, Division of General and Foregut Surgery, Policlinico San Donato, IRCCS, University of Milan, Milan, Italy luigi.bonavina@unimi.it

\section{E. Pisa · B. Di Venosa}

Division of Pathology, Istituto Europeo di Oncologia, IRCCS, Milan, Italy

\section{Prof. L. Bonavina}

Department of General and Foregut Surgery, IRCCS

Policlinico San Donato., Piazza Edmondo Malan, San Donato Milanese, 20097 Milan, Italy mass inside the left rectus abdominis muscle. A core biopsy of the lesion provided the diagnosis of cellular schwannoma and this was confirmed by histopathologic examination of the surgical specimen.

Conclusions Benign schwannoma of the abdominal wall is extremely rare. Percutaneous core needle biopsy is important for the differential diagnosis with more common and biologically more aggressive malignancies, such as desmoid tumors and sarcomas, and may be relevant for planning the most appropriate management.

Keywords Neurogenic tumors · Neurinoma ·

Neurilemmoma $\cdot$ Abdominal wall $\cdot$ Soft tissue tumors

\section{Main novel aspects}

- Differential diagnosis of an abdominal wall mass should include malignant tumors (desmoid, soft tissue sarcoma, and dermatofibrosarcoma protuberans), benign tumors (schwannoma, lipoma, and fibromatosis), and pseudo-tumors (hematoma, myositis, and nodular fasciitis).

- Preoperative histological diagnosis can easily be obtained by percutaneous core biopsy and is essential to define the appropriate surgical approach and to reduce the risk of undertreatment and local recurrence.

\section{Introduction}

Among tumors of the abdominal wall, desmoid tumors and sarcomas are the most represented [1, 2]. These are a heterogeneous group of malignant neoplasms with different biological behavior, metastatic potential, and rates of local recurrence after surgery. In contrast, schwannoma is a benign neurogenic tumor, also known as neurinoma or neurilemmoma, and represents approximately $5 \%$ of all benign soft- 
tissue neoplasms [3]. It is a slow-growing neoplasm, composed of Schwann cells, i.e., the glial cells forming the myelin sheath which is necessary for rapid propagation of the action potentials in nerve fibers [4]. Schwannoma is often asymptomatic, incidentally discovered during computed tomography (CT), and is usually located in the retroperitoneum, mediastinum, head and neck region, and upper and lower extremities. Schwannomas of the abdominal wall have rarely been reported. CT and magnetic resonance imaging (MRI) have emerged as the diagnostic modality of choice but the sensitivity remains low. A preoperative histological diagnosis obtained by percutaneous core needle biopsy has been considered essential to plan the correct surgical approach and reduce the risk of recurrence of soft tissue tumors [5]. Aim of this study was to analyze the literature and to discuss a new case of benign, cellular schwannoma of the abdominal wall.

\section{Materials and methods}

A literature review was performed to identify all English-written published articles on schwannoma of the abdominal wall in PubMed, EMBASE, and Web of Science database, using the keywords "schwannoma", "neurinoma", "neurilemmoma", "soft tissue tumors", "neurogenic tumor", "rectus abdominis mass", “abdominal wall", with "AND" and "OR". Based on the 2020 World Health Organization (WHO) classification of soft tissue tumors, the cases of schwannoma with malignant characteristics or incorporated in new

Table 1 Summary of reported cases of benign abdominal wall schwannoma in the English language literature

\begin{tabular}{|c|c|c|c|c|c|c|c|c|}
\hline & $\begin{array}{l}\text { Age } \\
\text { (years) } \\
\text { Sex (M/F) }\end{array}$ & Location & $\begin{array}{l}\text { Clinical } \\
\text { presenta- } \\
\text { tion }\end{array}$ & Imaging & $\begin{array}{l}\text { Preopera- } \\
\text { tive biop- } \\
\text { sy }\end{array}$ & Pathology & $\begin{array}{l}\text { S-100 } \\
\text { protein }\end{array}$ & $\begin{array}{l}\text { Follow-up } \\
\text { (months) }\end{array}$ \\
\hline $\begin{array}{l}\text { Bhatia, } \\
2010 \\
{[8]}\end{array}$ & $64, F$ & $\begin{array}{l}\text { Right iliac } \\
\text { fossa }\end{array}$ & $\begin{array}{l}\text { Asympto- } \\
\text { matic }\end{array}$ & CT: heterogeneous mass & No & $\begin{array}{l}\text { Macro: Tumor size } \\
60 \times 40 \times 35 \mathrm{~mm} \text {; ovoid, } \\
\text { solid cut superface } \\
\text { Micro: "ancient" Schwan- } \\
\text { noma }\end{array}$ & Positive & $\mathrm{n} / \mathrm{a}$ \\
\hline $\begin{array}{l}\text { Mishra, } \\
2013 \\
{[9]}\end{array}$ & $29, \mathrm{~F}$ & $\begin{array}{l}\text { Left upper } \\
\text { quadrant }\end{array}$ & $\begin{array}{l}\text { Asympto- } \\
\text { matic }\end{array}$ & $\begin{array}{l}\text { US: encapsulated, solid, flat, heterogeneous } \\
\text { mass. } \\
\text { MRl: hypointense on T1, heterogeneously } \\
\text { hyperintense on T2, cystic degeneration }\end{array}$ & No & $\begin{array}{l}\text { Macro: Tumor size } 60 \mathrm{~mm} \text {; } \\
\text { lobulated, pale yellow. } \\
\text { Micro: "ancient" Schwan- } \\
\text { noma }\end{array}$ & Positive & $\mathrm{n} / \mathrm{a}$ \\
\hline $\begin{array}{l}\text { Balzarotti, } \\
2014[10]\end{array}$ & $57, F$ & $\begin{array}{l}\text { Left lower } \\
\text { quadrant }\end{array}$ & Pain & $\begin{array}{l}\text { US: hypoechoic mass with internal hyperechoic } \\
\text { linear structures. } \\
\text { CT: regular oval shape, homogenous soft } \\
\text { mass density, homogenous enhancement after } \\
\text { contrast }\end{array}$ & No & $\begin{array}{l}\text { Macro: Tumor size } 20 \mathrm{~mm} \text {; } \\
\text { rounded, tense-elastic con- } \\
\text { sistency. } \\
\text { Micro: Schwannoma }\end{array}$ & Positive & 12 \\
\hline $\begin{array}{l}\text { Ginesu, } \\
2016 \\
{[11]}\end{array}$ & $62, F$ & $\begin{array}{l}\text { Right iliac } \\
\text { fossa }\end{array}$ & Pain & $\begin{array}{l}\text { US: hypoechoic mass. } \\
\text { CT: well-circumscribed mass, internal calci- } \\
\text { fications, little enhancement after contrast }\end{array}$ & No & $\begin{array}{l}\text { Macro: Tumor size } \\
58 \times 40 \times 46 \mathrm{~mm} \text {; } \\
\text { ovoid } \\
\text { Micro: "ancient" Schwan- } \\
\text { noma }\end{array}$ & $\mathrm{n} / \mathrm{a}$ & 1 \\
\hline $\begin{array}{l}\text { Basu, } 2018 \\
{[12]}\end{array}$ & $22, \mathrm{M}$ & $\begin{array}{l}\text { Left upper } \\
\text { quadrant }\end{array}$ & $\begin{array}{l}\text { Asympto- } \\
\text { matic }\end{array}$ & $\begin{array}{l}\text { US: encapsulated, ovoid, heterogeneously } \\
\text { hypoechoic mass } \\
\text { MRl: hypointense on T1, hyperintense on T2 } \\
\text { and on fat-suppression }\end{array}$ & No & $\begin{array}{l}\text { Macro: Tumor size } \\
60 \times 37 \times 32 \mathrm{~mm} ; \\
\text { ovoid, pale yellow } \\
\text { Micro: Schwannoma }\end{array}$ & $\mathrm{n} / \mathrm{a}$ & $\mathrm{n} / \mathrm{a}$ \\
\hline $\begin{array}{l}\text { Lam, } 2019 \\
{[13]}\end{array}$ & $70, \mathrm{M}$ & $\begin{array}{l}\text { Left lower } \\
\text { quadrant }\end{array}$ & Pain & $\begin{array}{l}\text { US: encapsulated, solid, heterogeneously } \\
\text { hypoechoic mass }\end{array}$ & No & $\begin{array}{l}\text { Macro: Tumor size } \\
9 \times 9 \times 10 \mathrm{~mm} ; \\
\text { Ovoid } \\
\text { Micro: Schwannoma }\end{array}$ & Positive & 1 \\
\hline $\begin{array}{l}\text { Paramy- } \\
\text { thiotis, } \\
2019[14]\end{array}$ & $52, \mathrm{M}$ & $\begin{array}{l}\text { Left upper } \\
\text { quadrant }\end{array}$ & Pain & $\begin{array}{l}\text { CT: well-circumscribed mass. } \\
\text { MRl: hypointense on T1, hyperintense on T2 } \\
\text { and on fat-suppression }\end{array}$ & No & $\begin{array}{l}\text { Macro: Tumor size } \\
65 \times 45 \times 35 \mathrm{~mm} \text {; ovoid } \\
\text { Micro: Schwannoma }\end{array}$ & Positive & 12 \\
\hline $\begin{array}{l}\text { Tarchouli, } \\
2020 \\
{[15]}\end{array}$ & $34, \mathrm{M}$ & $\begin{array}{l}\text { Right iliac } \\
\text { fossa }\end{array}$ & Pain & $\begin{array}{l}\text { US: solid, heterogeneous mass. } \\
\text { CT: regular oval shape mass with homogenous } \\
\text { density, mild and homogenous enhancement } \\
\text { after contrast }\end{array}$ & No & $\begin{array}{l}\text { Macro: Tumor size } \\
70 \times 70 \times 50 \mathrm{~mm} ; \\
\text { ovoid } \\
\text { Micro: Schwannoma }\end{array}$ & Positive & $\mathrm{n} / \mathrm{a}$ \\
\hline $\begin{array}{l}\text { Alsahwan, } \\
2021 \\
{[16]}\end{array}$ & $25, \mathrm{M}$ & $\begin{array}{l}\text { Left upper } \\
\text { quadrant }\end{array}$ & Pain & $\begin{array}{l}\text { US: encapsulated, heterogeneously hypoe- } \\
\text { choic mass with mildly increased peripheral } \\
\text { vascularity }\end{array}$ & No & $\begin{array}{l}\text { Macro: Tumor size } 32 \mathrm{~mm} \text {; } \\
\text { rounded } \\
\text { Micro: "ancient" Schwan- } \\
\text { noma }\end{array}$ & Positive & $\mathrm{n} / \mathrm{a}$ \\
\hline $\begin{array}{l}\text { Present } \\
\text { case }\end{array}$ & $58, \mathrm{M}$ & $\begin{array}{l}\text { Left upper } \\
\text { quadrant }\end{array}$ & $\begin{array}{l}\text { Asympto- } \\
\text { matic }\end{array}$ & $\begin{array}{l}\text { US: well-circumscribed, hypoechoic. MRI: } \\
\text { hypointense on T1, hyperintense on T2 and on } \\
\text { fat-suppression }\end{array}$ & Yes & $\begin{array}{l}\text { Macro: Tumor size: } \\
64 \times 42 \times 30 \mathrm{~mm} \text {; } \\
\text { ovoid } \\
\text { Micro: cellular Schwannoma }\end{array}$ & Positive & 6 \\
\hline
\end{tabular}



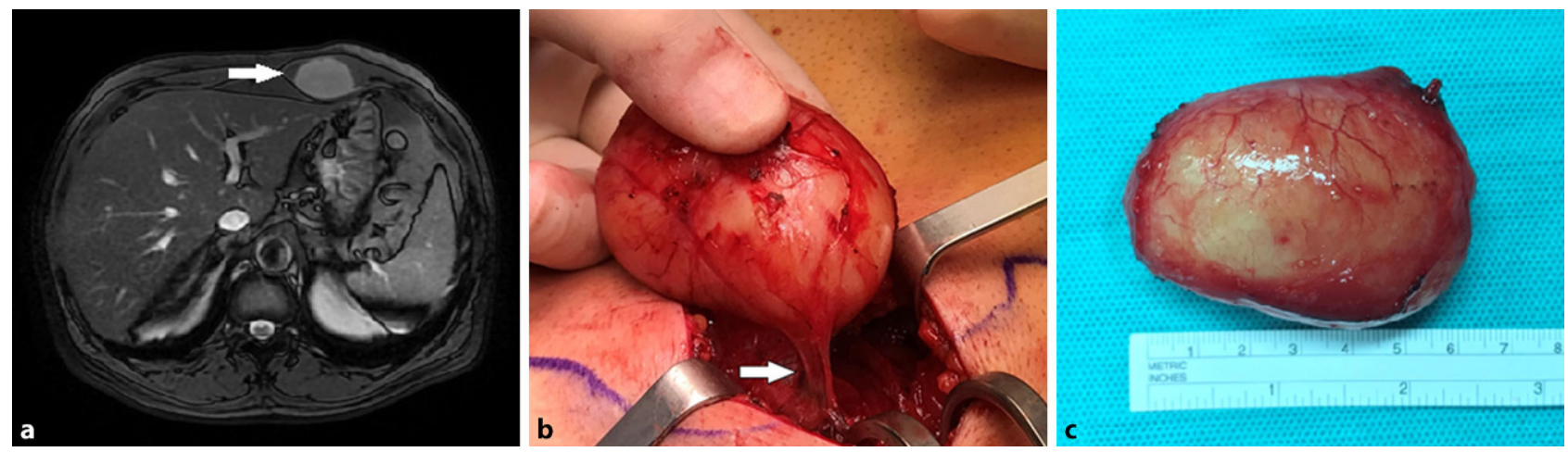

Fig. 1 Increased signal intensity of the lesion on fat-suppressed T2-weighted MRI (arrow) (a). Tumor with peripheral location of the affected nerve (arrow) (b). Resected specimen (c)

recognized entities and subtypes, were excluded $[6$, 7].

We also consulted the hospital electronic database to find the records of patients admitted for treatment of abdominal wall tumors. Demographic and clinical patient data were extracted from the hospital charts. Written informed consent was obtained from patients.

\section{Results}

Our literature search yielded 12 single case reports published between 2001 and March 2021, and 9 of these were included in the review [8-16]. According to the WHO classification of soft tissue tumors, we excluded 3 case reports ( 1 schwannoma with melanocytic differentiation, 1 malignant, 1 with low malignant potential) [17-19].

The main demographic and clinical characteristics of the patients included in the review are summarized in Table 1. The median age was 52 (range 22-70), and the sex distribution was similar. The tumor was more frequently located in the left anterolateral upper abdominal quadrant (44.5\%), and pain was reported by $6(66.6 \%)$ patients. No preoperative biopsy was performed. Histology of the surgical specimen showed an "ancient" morphologic variant in 4 patients $(44.4 \%)$. Follow-up was reported in 4 patients and ranged from 1 to 12 months. No local recurrences were reported.
In addition to the narrative review, we analyzed the clinical characteristic of a 58-year-old man referred for surgical evaluation of a palpable mass in the proximal portion of the left rectus abdominis muscle, just below the costal margin. The patient noted a progressive enlargement of the mass, not associated with pain, paresthesia or other symptoms. Medical history included hypertension, type 2 diabetes, and coronary artery disease with previous angioplasty and stent placement. On physical examination, a large oval-shaped solid mass with regular borders was palpable. Ultrasonography demonstrated a hypoechoic area inside the left rectus abdominis muscle, wellencapsulated and with regular borders and vascularization. MRI with gadolinium confirmed the presence of $64 \times 42 \times 30 \mathrm{~mm}$ mass, with low intensity signal on T1-weighted images, heterogeneous increased signal intensity on T2-weighted images, hyperintensity on diffusion-weighted images with corresponding hypointensity on apparent diffusion coefficient images (Fig. 1a). An ultrasound-guided core needle biopsy of the lesion showed spindle-cell proliferation, without evidence of dysplasia and malignancy, and immunohistochemistry revealed a diffusely cellular expression of S100 protein, suggesting the diagnosis of schwannoma. Laboratory tests and oncologic markers were within normal ranges. Under general anesthesia, a $5 \mathrm{~cm}$ incision over the mass was performed. The tu-
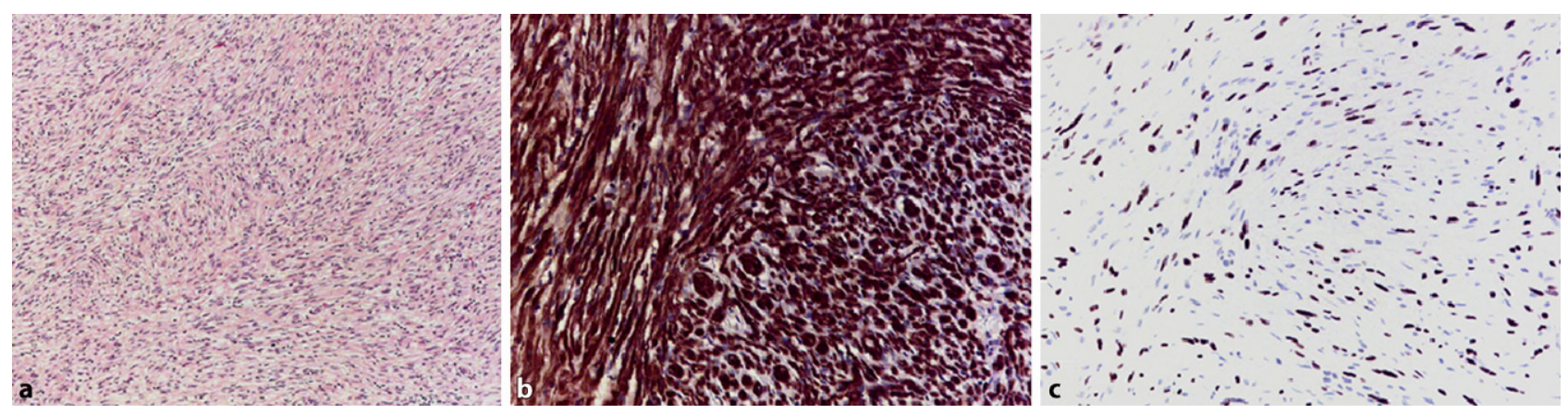

Fig. 2 Proliferation of Schwann cells in long fascicles (Antoni A areas), without Antoni B areas or Verocay bodies (a). S100 protein (b) (nuclear and cytoplasmic positivity) and SOX-10 (c) (nuclear positivity) immunostains of cellular schwannoma 
mor was identified just below the left rectus abdominis sheath and was completely resected with preservation of both anterior and posterior muscle sheaths (Fig. 1b,c). Macroscopically, it appeared as a welldemarcated and solid tumor, without cystic degeneration. Microscopic findings revealed proliferation of spindle cells with twisted nuclei, arranged in intersecting or long fascicles. The tumor was composed exclusively of Antoni A areas, without cellular palisades, Verocay bodies or Antoni B areas (Fig. 2a). Mitotic activity was low (2 mitoses/10 hpf [high power field]), with mild nuclear atypia despite the high cellularity of the neoplasm. Immunohistochemically, the tumor displayed diffuse and strong positivity for S100 protein and SOX-10, diffuse positivity for CD34, negativity for c-Kit, DOG-1, calretinin, EMA (Epithelial Membrane Antigen), desmin, and TTF-1, and retained the nuclear expression of Histone (H3K27me3) (Fig. 2b,c). The positivity for CD34, the intense positivity for S100 and SOX-10 and the negativity for c-Kit, DOG1 and calretinin excluded the diagnosis of gastrointestinal stromal tumor and neurofibroma and were compatible with the diagnosis of "cellular schwannoma". The post-operative course was regular. At 6-month followup, the patient was doing well and an abdominal wall ultrasound revealed no signs of tumor recurrence.

\section{Discussion}

This study shows that schwannoma of the abdominal wall is an extremely rare tumor, with only few cases reported in the literature over the past decade. Sporadic schwannomas represent approximately $5 \%$ of all benign soft-tissue tumors; however, distinct autosomal-dominant diseases, such as neurofibromatosis-2 and schwannomatosis, predispose to the growth of multiple tumors [20]. Most commonly, schwannoma develops in the retroperitoneum (32\%), mediastinum (23\%), head and neck region (18\%), and upper and lower extremities (16\%) [21], but cases of schwannoma in the thoracic [22] and abdominal wall [8-19] are also reported.

Benign schwannomas are often asymptomatic and may be incidentally discovered in a CT scan [8]; however, pain, paresthesia or weakness due to nerve compression may occur, depending on tumor size and location. Ultrasonography is the first-line diagnostic test for superficial soft tissue schwannomas. CT and MRI with gadolinium contrast permit a more detailed study, but still do not allow to distinguish with certainty schwannomas from other benign and malignant tumors. MRI can provide additional information on the cleavage planes. A homogenous isointense or low intensity signal relative to skeletal muscle on T1-weighted images, and a heterogeneous increased signal intensity with biphasic pattern on T2-weighted images are typical MRI features [23-26]. The eccentric position in relation to the nerve, the fusiform shape, the split-fat sign, and the MRI "target sign" can be useful in differentiating schwannoma from other neurogenic tumors [27]. However, sensitivity and specificity rates for diagnosis of malignant peripheral nerve sheath tumors (MPNST) based on imaging alone are $61 \%$ and $90 \%$, respectively [28]. Therefore, a preoperative histological diagnosis remains essential for planning appropriate management. Percutaneous core needle biopsy is a simple and safe procedure, and can differentiate malignant from benign soft tissue tumors with a $96.3 \%$ sensitivity, $99.4 \%$ specificity, and $97.6 \%$ accuracy. Moreover, tumors subtype were correctly identified in $89.5 \%$ of benign tumors and $88.0 \%$ of soft tissue sarcomas [5]. This is critical, since desmoid and sarcoma still represent $45 \%$ and $40 \%$ of all abdominal wall neoplasms, respectively, and require a fullthickness abdominal wall resection with wide margin of normal tissue [29]. On the contrary, schwannoma requires a more conservative surgical approach, with a negligible risk of local recurrence in case of complete tumor removal [2, 30, 31].

Currently, the term malignant schwannoma is obsolete. Rather, tumors deriving from Schwan cells are now defined as malignant peripheral nerve sheath tumors (MPNST) and those with melanocytic differentiation are defined malignant melanotic nerve sheath tumors (MMMST). These tumors have an aggressive clinical behavior, early age at presentation, and are frequently associated with autosomal dominant syndromes [6, 7, 32]. Macroscopically, schwannoma appears as a well-circumscribed mass with rounded or ovoid shape and smooth surface. At microscopic analysis two alternating patterns of growth, "Antoni A" and "Antoni B" are usually described. The highly cellular "Antoni A" areas are composed of spindle cells organized to form long bundles with nuclear palisading and occasionally "Verocay bodies", formed by two compact rows of well-aligned nuclei separated by fibrillary cell processes. The myxoid "Antoni B" pattern is looser, less ordered, with areas of microcystic and xanthomatous change, inflammatory cells, and hyalinization with partially thrombosed vessels. Mitotic activity is rare. Immunohistochemically, schwannoma demonstrates diffuse positivity for S100 protein and SOX-10 [33, 34]. Several morphologic variants of schwannoma are well recognized, including cellular schwannoma, plexiform schwannoma, epithelioid schwannoma, "ancient” schwannoma, and mixed forms of schwannoma with neurofibroma. The "Antoni A" and "Antoni B" areas are present in different proportion [35]. In our case, the tumor was composed exclusively of Antoni A areas. Schwannomas composed exclusively or predominantly of "Antoni A" areas are defined "cellular schwannomas", characterized by a high cellularity, fascicular pattern, occasional nuclear hypercromasia and atypia, and mitotic activity (usually $<4$ mitoses/10 hpf). The histopathological findings of degenerative changes such as calcification, interstitial fibrosis, hemosiderin deposition, cystic and vascular hyaline degenera- 
tion characterize another subtype of schwannoma, defined as "ancient" $[8,9,11,13,16,27]$. The histological features of high cellularity, fascicular pattern, occasional nuclear hypercromasia and atypia, mitotic activity can lead to an erroneous diagnosis of MPNST. However, the cellularity too high compared to the number of mitoses, the perivascular hyalinization, occasional "Antoni B" areas and strong positivity for S100 protein and SOX-10, suggest a benign diagnosis. Since well-differentiated leiomyosarcoma can also show nuclear palisading aspects and positivity for S100 protein, SOX-10 positivity, which is never expressed in leiomyosarcoma, is useful for the differential diagnosis [36].

In conclusion, we reported a rare case of cellular schwannoma of the abdominal wall and compared our findings and principal features of this benign tumor with the current literature. We underlined the importance of preoperative imaging and percutaneous core needle biopsy to avoid undertreatment or overtreatment. Patients who are preoperatively diagnosed with desmoid tumor or sarcoma of the abdominal wall should preferably be managed in referral centers where a multidisciplinary approach can be provided by a specialized team.

Funding Open access funding provided by Università degli Studi di Milano within the CRUI-CARE Agreement.

\section{Declarations}

Conflict of interest T. Panici Tonucci, A. Sironi, E. Pisa, B. Di Venosa and L. Bonavina declare that they have no competing interests.

Ethical standards All procedures performed in studies involving human participants or on human tissue were in accordance with the ethical standards of the institutional and/or national research committee and with the 1975 Helsinki declaration and its later amendments or comparable ethical standards. Informed consent was obtained from all individual participants included in the study. Internal review board approval HSD 2020-077.

Open Access This article is licensed under a Creative Commons Attribution 4.0 International License, which permits use, sharing, adaptation, distribution and reproduction in any medium or format, as long as you give appropriate credit to the original author(s) and the source, provide a link to the Creative Commons licence, and indicate if changes were made. The images or other third party material in this article are included in the article's Creative Commons licence, unless indicated otherwise in a credit line to the material. If material is not included in the article's Creative Commons licence and your intended use is not permitted by statutory regulation or exceeds the permitted use, you will need to obtain permission directly from the copyright holder. To view a copy of this licence, visit http://creativecommons.org/licenses/by/4.0/.

\section{References}

1. Brennan MF, Antonescu CR, Moraco N, Singer S. Lessons learned from the study of 10.000 patients with soft tissue sarcoma. Ann Surg. 2014;260:416-21.

2. Smith HG, Tzanis D, Messiou C, et al. The management of soft tissue tumours of the abdominal wall. Eur J Surg Oncol. 2017;43(9):1647-55.

3. Kransdorf MJ. Benign soft-tissue tumors in a large referral population: distribution of specific diagnoses by age, sex, and location. AJRAm J Roentgenol. 1995;164(2):395-402.

4. Salzer JL. Schwann cell myelination. Cold Spring Harb PerspectBiol. 2015;7(8):a20529.

5. Strauss DC, Qureshi YA, Hayes AJ, et al. The role of core needle biopsy in the diagnosis of suspected soft tissue tumours. J Surg Oncol. 2010;102(5):523-9.

6. ChoiJH, RoJY.The2020WHOclassification of tumors of soft tissue: selected changes and new entities. Adv Anat Pathol. 2021;28(1):44-58.

7. Kallen ME, HornickJL. The 2020 WHOclassification: what's new in soft tissue tumor pathology? Am J Surg Pathol. 2021;45(1):e1-e23.

8. Bhatia RK, Banerjea A, Ram M, et al. Benign ancient schwannoma of the abdominal wall: an unwanted birthday present. BMCSurg. 2010;10:1.

9. Mishra A, Hamadto M, Azzabi M, et al. Abdominal wall schwannoma: case report and review of the literature. Case Rep Radiol. 2013;2013:456863.

10. Balzarotti R, Rondelli F, Barizzi J, et al. Symptomatic schwannoma of the abdominal wall: a case report and review of the literature. Oncol Lett. 2015;9(3):1095-8.

11. Ginesu GC, Puledda M, Feo CF, et al. Abdominal wall Schwannoma. J Gastrointest Surg. 2016;20(10):1781-3.

12. Basu S. Benign schwannoma of the abdominal wall: a rare case report and a review of literature. Ind J Case Rep. 2018;4(3):250-2.

13. Lam R, Hunt BL, Arreola-Owen O. Abdominal Wall Schwannoma. Fed Pract. 2019;36(3):129-33.

14. Paramythiotis D, Pagkou D, Moysidis M, et al. External oblique muscle Schwannoma: a rare anatomical presentation. Case Rep Surg. 2019; https://doi.org/10.1155/2019/ 9290821.

15. Tarchouli M, Essarghini M, Qamouss O, et al. Abdominal wall schwannoma: a case report. Gastroenterol Hepatol Bed Bench. 2020;13(1):95-100.

16. Alsahwan AG, Felemban JM, Al-Othman A, et al. Symptomatic abdominal wall Schwannoma mimicking infected Subcutanous soft tissuelesion. A case report. Int JSurg Case Rep. 2021;81:105751. https://doi.org/10.1016/j.ijscr.2021. 105751.

17. Lazaros GA, Panagiotides HC, Ioakimidis DE, et al. A muscle mass in a patient with polymyalgia rheumatica. J Clin Rheumatol. 2001;7(6):395-9.

18. Khorgami Z, Nasiri S, Rezakhanlu F, et al. Malignant schwannoma of anterior abdominal wall: report of a case. JClin Med Res. 2009;1(4):233-6.

19. Liu Y, Chen X, Wang T, et al. Imaging observations of a schwannoma of low malignant potential in the anterior abdominal wall: a case report. Oncol Lett. 2014;8(3):1159-62.

20. Evans DG, Bowers NL, Tobi S, et al. Schwannomatosis: a genetic and epidemiological study. J Neurol Neurosurg Psychiatry. 2018;89(11):1215-9.

21. White W, Shiu MH, Rosenblum MK, et al. Cellular schwannoma. A clinicopathologic study of 57 patients and 58 tumors. Cancer. 1990;66(6):1266-75. 
22. Urakawa T, Kawakita N, Nagahata Y. A case of benign schwannoma of the thoracic wall mimicking a malignant tumor. Kobe J Med Sci. 1993;39(4):123-31.

23. Koga H, Matsumoto S, Manabe J, et al. Definition of the target sign and its use for the diagnosis of schwannomas. Clin Orthop Relat Res. 2007;464:224-9.

24. Beaman FD, KransdorfMJ, MenkeDM. Schwannoma: radiologic-pathologic correlation. Radiographics. 2004;24(5):1477-81.

25. Murphey MD, Smith WS, Smith SE, et al. From the archives of the AFIP. Imaging of musculoskeletal neurogenic tumors: radiologic-pathologic correlation. Radiographics. 1999;19(5):1253-80.

26. Lin J, Martel W. Cross-sectional imaging of peripheral nerve sheath tumors: characteristic signs on CT, MR imaging, and sonography. AJRAm J Roentgenol. 2001;176(1):75-82.

27. Albert P, Patel J, Badawy K, et al. Peripheral nerve Schwannoma: a review of varying clinical presentations and imaging findings. J Foot Ankle Surg. 2017;56(3):632-7.

28. Wasa J, NishidaY,TsukushiS, etal. MRIfeatures in the differentiation of malignant peripheral nerve sheath tumors and neurofibromas. AJRAmJ Roentgenol. 2010;194(6):1568-74.

29. Stojadinovic A, Hoos A, Karpoff HM, et al. Soft tissue tumors of the abdominal wall. Analysis of disease patterns and treatment. Arch Surg. 2001;136:70-9.
30. Wilder F, D'Angelo S, Crago AM. Soft tissue tumors of the trunk: management of local disease in the breast and chest and abdominal walls. J Surg Oncol. 2015;111(5):546-52.

31. Pencavel T, Strauss DC, Thomas JM, et al. The surgical management of soft tissue tumours arising in the abdominal wall. Eur J Surg Oncol. 2010;36(5):489-95.

32. James AW, Shurell E, Singh A, et al. Malignant peripheral nerve sheath tumor. Surg Oncol Clin N Am. 2016;25(4):789-802.

33. Elder DE, Massi D, Scolyer RA, Willemze R. WHO classification of skin tumours: WHOclassification of tumours. 4 th ed. Vol. 11;2020.

34. Fletcher CDM, Bridge JA, Hogendoorn PCW, et al. WHO classification of tumours of soft tissue and Bone: WHO classification of tumours. 4th ed. Vol. 5;2020.

35. Meyer A, Billings SD. What's new in nerve sheath tumors. Virchows Arch. 2020;476(1):65-80.

36. Pekmezci M, Reuss DE, Hirbe AC, et al. Morphologic and immunohistochemical features of malignant peripheral nerve sheath tumors and cellular schwannomas. Mod Pathol. 2015;28(2):187-200.

Publisher's Note Springer Nature remains neutral with regard to jurisdictional claims in published maps and institutional affiliations. 